\title{
Liposuction-induced fat embolism syndrome
}

\author{
Colby A Cantu, Elizabeth N Pavlisko
}

Department of Pathology, Duke University Hospital, Durham, North Carolina, USA

\section{Correspondence to}

Dr Colby A Cantu colby.cantu@gmail.com

Accepted 24 March 2017

\section{CrossMark}

\section{To cite: Cantu CA,} Pavlisko EN. BMJ Case Rep Published Online First: [please include Day Month Year]. doi:10.1136/bcr-2017219835

\section{DESCRIPTION}

Three days after undergoing an elective liposuction procedure, a 60 -year-old woman presented to her local emergency department with shortness of breath and lethargy.

Physical examination was remarkable for abdominal distention, bilateral lower extremity swelling and hypoxaemia. Bilevel positive airway pressure (BiPAP) trial was initiated but it was unable to sustain adequate oxygen saturation; consequently, the patient was intubated and mechanically ventilated. Pulmonary thromboembolism was suspected, but a chest CT scan was contraindicated due to acutely poor kidney function. Therefore, heparin infusion was introduced, but the patient further deteriorated and expired shortly thereafter.

Medical autopsy was conducted to determine the cause of death. Gross findings were significant for acute pulmonary thromboemboli of the segmental and subsegmental arteries of the bilateral lungs and pulmonary lobar consolidation. Surprisingly, brain sectioning revealed diffuse, petechial haemorrhages of the white matter of the cerebral cortex, cerebellum and spinal cord (figure 1).

Microscopic findings on formalin-fixed, paraffin-embedded tissue stained with haematoxylin and eosin further supported acute pulmonary thromboemboli and acute bronchopneumonia. In addition, microscopic brain findings were significant for diffuse petechial haemorrhage of white matter, and cerebral vascular occlusion by fibrin and adipocytes. Suspicion for systemic fat emboli was raised, so osmium tetroxide staining was performed on

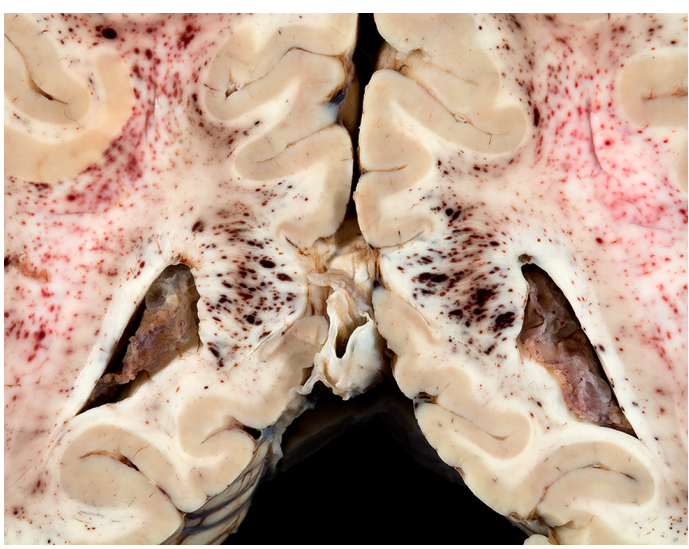

Figure 1 White matter petechial haemorrhages of the cerebral cortex.

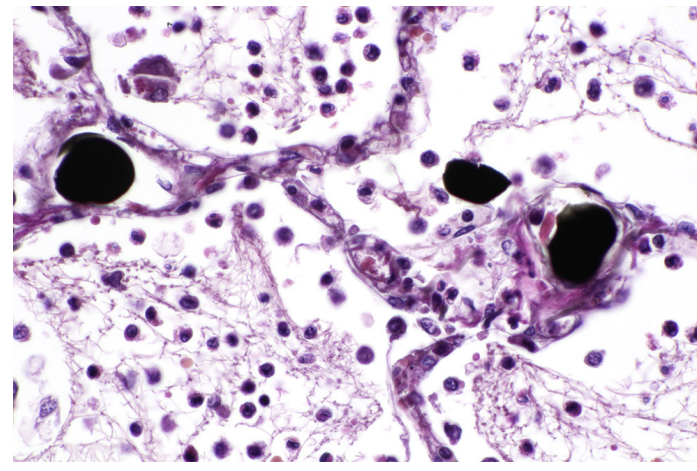

Figure 2 Osmium tetroxide stained fat embolus of pulmonary vasculature (haematoxylin and eosin stain, original magnification $\times 40$ ).

lung sections, which highlighted extensive involvement of fat emboli (figure 2).

Liposuction is regarded as a safe procedure with few risks, and the number of procedures have increased by $124 \%$ since 1997 when plastic surgery statistics were first recorded. ${ }^{1}$ To the best of our knowledge, this is only the 16th case of liposuction-induced fat embolism syndrome.

\section{Learning points}

- This study represents only the 16 th case of liposuction-induced fat embolism syndrome.

- Liposuction is not a risk-free procedure and potentially fatal complications may occur.

- Detailed clinical history and astute clinical suspicion are necessary for recognition of postmortem fat embolism, because fat emboli are difficult to identify with routine tissue processing and staining.

Contributors CAC and ENP were involved in the clinical care of the patient. Each contributed towards the collection of relevant data and images, drafting of the manuscript and revision of the paper.

Competing interests None declared.

Patient consent Consent obtained from next of kin.

Provenance and peer review Not commissioned; externally peer reviewed.

(c) BMJ Publishing Group Ltd (unless otherwise stated in the text of the article) 2017. All rights reserved. No commercial use is permitted unless otherwise expressly granted.

\section{REFERENCE}

1 The American Society for Aesthetic Plastic Surgery. Cosmetic surgery national data bank statistics. 2015. http://www.surgery. org/sites/default/files/ASAPS-Stats2015.pdf (accessed 7 Apr 2017). 
Images in...

Copyright 2017 BMJ Publishing Group. All rights reserved. For permission to reuse any of this content visit http://group.bmj.com/group/rights-licensing/permissions.

BMJ Case Report Fellows may re-use this article for personal use and teaching without any further permission.

Become a Fellow of BMJ Case Reports today and you can:

- Submit as many cases as you like

- Enjoy fast sympathetic peer review and rapid publication of accepted articles

Access all the published articles

- Re-use any of the published material for personal use and teaching without further permission

For information on Institutional Fellowships contact consortiasales@bmjgroup.com

Visit casereports.bmj.com for more articles like this and to become a Fellow 